\title{
THE SOCIETY FOR THE PROMOTION OF HELLENIC STUDIES
}

\author{
31-34 Gordon SQUare, London, WC1H OPP
}

\section{HONORARY MEMBERS}

\author{
Akurgal, Prof. E., Dil Tarin Fakultesi, Ankara Universitesi, Ankara, Turkey. \\ Amandry, Prof. Pierre, Ecole francaise, Didolou 6, Athens, Greece. \\ Bengtson, Prof. H., Universität München, 8000 München 22, Germany. \\ Chantraine, Prof. Pierre, 38 bis rue Boulard, Paris XIVe, France. \\ Cherniss, Prof. H., Institute for Advanced Study, Princeton, New Jersey, U.S.A. \\ Daux, Prof. G., 6 Avenue Paul Appell, Paris XIVe, France. \\ Dow, Prof. S., Widener Library, 690, Cambridge 38, Mass., U.S.A. \\ Festugière, A.-J., O.P., 222, Rue du Faubourg Saint-Honoré, Paris VIIIe, France. \\ Flacelière, Prof. R., Université de Paris-Sorbonne, Place de la Sorbonne, Paris Ve, France. \\ Haspels, Prof. C. H. E., Archaeologisch-Historisch Instituut, Oude Turfmarket 129, Amsterdam, Netherlands. \\ Karouzou, Mrs. S. P., National Museum, Athens, Greece. \\ Kunze, Dr. E., 8021 Grosshesselohe bei München, Immergrünsirasse 1, Germany. \\ Langlotz, Dr. Ernst, 53 Bonn-Ippendorf, Hohenweg 75, Germany. \\ I esky, Prof. Albin, Alserstrasse 69/17, Vienna 8, Austria. \\ Merit t, Prof. B. D., 712 West 16th St., Austin, Texas, U.S.A. \\ Neugebauer, Prof. O., Brown University, Providence, Rhode Island, U.S.A. \\ Orlandos, Prof. A. C., Navarinou Street, 6, Athines, Greece. \\ Pfeiffir, Prof. R., Hiltenspergerstrasse 21/0, Munich 13, Germany. \\ Platon, Dr. N., The Acropolis Museum, Athens, Greece. \\ Robert, Prof. L., 31 Avenue Parc de Montsouris, Paris XIVe, France. \\ Romilly, Prof. J. de, 12 rue Chernoviz, Paris XVIe, France. \\ Sambursky, Prof. S., Israel Academy of Sciences and Humanities, Ferusalem, Istael. \\ Schaeffer, Dr. C. F. A., Le Castel Blane, 14 Rue Turgot, St. Germain-en-Laye, France. \\ Snell, Prof. Bruno, 2 Hamburg 13, Heimherderstrasse 80, Germany. \\ Solmsen, Prof. F., 810 Old Mill Road, Chapel Hill, North Carolina 27514, U.S.A. \\ Strasburger, Prof. H., Urachstrasse 37, 78 Freiburg, Germany. \\ Thompson, Mrs. D. B., Institute for Advanced Study, Princeton, New Jersey, U.S.A. \\ Thompson, Prof. Homer A., Institut for Advanced Study, Princeton, New Jersey, U.S.A. \\ Vlastos, Prof. G., Princeton University, Princeton, New Jersey, U.S.A. \\ White, Prof. Mary E., Trinity College, Toronto 5, Canada. \\ Youtic, Prof. H. C., University of Michigan, Ann Arbor, U.S.A. \\ Zancani Montuoro, Signora P., Il Pizzo, S. Agnello di Sorrento, proo. Napoli, Italy.
}




\title{
The Society for the Promotion of Hellenic Studies
}

31-34 Gordon SQuare, London, WClH 0PP

President: Professor ROBERT Browning.

The Society, founded in 1879 to advance the study of Greek language, literature history and art, maintains conjointly with the Society for the I'rumotion of Roman Studies and in association with the Institute of Classical Studies of the University of London.

1. A Library of some 45,000 volumes, containing many costly works and rare periodicals.

2. Some 4,000 coloured slides covering a wide variety of subjects, sets of slides with lecture texts, and film strips.

Books and slides can be sent to Members by post. Communications about books and slides should be addressed to the Librarian at the above address.

Four general meetings, with lectures, are held in London annually, and there are other meetings in different parts of the country.

Subscribers receive free the Society's two annual publications: The Journal of Hellenic Studies, one of the foremost Britisb periodicals in the field of Greek scholarship, containing articles, illustrations and book reviews; A rchaeological Reports, a fully illustrated account of fresh discoveries in (ireece and Greek lands, with bulletins announcing important new acquisitions by museums in Britain.

These two periodicals are on sale to the general public.

The annual subscription to the suciety is $\$ 4.50$. The Composition fee for life-membership is $f 15$ for thuse over 65 years of age, after 5 years nembership. The subscription for Libraries and Student Associates is $£^{5.60}$ and $£ 1.50$ respectively. There is no entrance fee.

Applications for membership or inquiries about the Society showld be addressed to the Secretary Telephone 01-387 7495 .

\section{The Society for the Promotion of Roman Studies}

\author{
31-34 GORDON SQUARE, LONDON, WC1H OPP
}

President: Mr. A. N. Sherwin-White, F.B.A.

The Society was formed in 1910 to promote the study of the archaeology, art, literature, and history of Italy and the Roman Empire down to about the year A.D. 700, by publishing journals, forming a library, and holding meetings.

The Journal of Roman Stkdies is published annually and contains articles written by leading British and foreign scholars and reviews of recent publications. It is abundantly illustrated. The Society also published Britannia, devoted to Romiano-British and conius the annual survey of Romano-British excavations, previously published in the Joumal is now transferred. The survey continues to be available as an offprint.

The Society maintains, in conjunction with the Hellenic Society, a joint library of works on classical antiquity and a collection of lantern slides. Members are entitled to borrow books and slides, which can be sent to them by post, and may also consult books in the library of the London University Institute of Classical Studies, which is complementary to that of the Societies.

The annual subscription is $£ 4.50$ which entitles members to one of the journals, or $£ 8.25$ for both. Institutions, except schools, pay the full rate for the two. Life membership for those of 65 or over $t 15$. Student-associates $£ 2.25$.

All inquiries should be addressed to the Secretary. Telephone 01-387-8157.

The following may be obtained from The Hellenic Society, 31-34 Gordon Square, London, WC1H OPP.

1. LIST OF THE WRITINGS OF J. D. BEAZLEY. Oxford 1951. Price $£ 0.75$.

3. Supplemertary Papers

No. VI CORINNA

By D. L. Page. 88 pages. Demy 8 vo. Reprint. Price $£^{0.63}$

No. VIII THE GREEKS AND THEIR EASTERN NEIGHBOURS

By T. J. Dunbabin. Microfilm copies are available from University Microfilms, Ann Arbor, Michigan 48106.

No. IX THE GREEK ANTHOLOGY: SOURCES AND ASCRIPTIONS

No. $x \quad$ ISLA.ND GEMS

By John Boardinan 170 pages. 20 plates. Demy 8 vo. Irice $€ 1.50$.

No. XI EURIPIDES AND THE JUDGEMENT OF PARIS

By T. C. W. Stinton. 80 pages. 8 plates. Demy 8 vo. Price $\mathfrak{f}_{0.87}$

No. XII THE SANTORINI VOLCANO AND THE DESOLATION OF MINOAN CRETE

by D. L. Page. 45 pages. 20 plates. Crown 4 to. Price 61.20

Note: Supplimentary Papers $I, I I, I I I, I V, V, V I I$ and VIII, are out of print.

\section{THE GLASSIGAL ASSOGIATION}

The main ains of the Classical Assnciation are to promote and sustain interest in classical studies, to maintain their rightful position in universities and schonls, and to give scholars and teachers opportunities of meeting and discussing their problems. It organises an annual conference, lasting four or five days, in a university centre, and sponsors over 30 branches, which arrange programmes of lectures and discussions and nany of which hoid Greek and Latin Realing Competitions for Schools. Its activities are fully reported in its annual Proceedings, issued free to all members.

The present rnembership of the Association is approximately 4,500. Membership is open both to individuals and to institutions (the rates of anvual aud life-subscription are presently under review). Members may obtain the Classical Review and Classical Quarlerly at reduced prices (Rerice, 25. (unarterly, 66.25; combined subscription $f 11.50)$. Greece and Rome may also be obtained through the Association for an annual sulscription of $\ell 3.25$. Applications for membership and subscriptions for the journais (which should normally be received by Jantary 31 st in each year) should be addressed to the Treasurer, Mr. G. R. Watson, Dept. of Classics, The University, Nottingham NGi 2 RD.

The Association can also sunply copies of the Index to the First Series of the Classical Revicw (price $f 1.25$ for mernbers, $€ l .50$ for nonmembers, post free) and of the last two issues of The Year's Work in Classical Studies, covering the years $1939-47$ and $1945-47$ (price fo.30 each volume, post free). These publications and details of the various occasional publications of the Association, including all Supflenints to Greece and Rome, are obtainable from the Treasurer. Inquiries, other than about membership and publications, should be sent to either of the Secretaries (Prof. C. Collard, University College, Singleton Park, Swansea SA2 8PP, and Miss E. M. Tucker, Cbrist's Hospital School for Girls, Hertíord.

Contributions to the JOURNAL should be sent to Dr. J. K. Davies, Oriel College, Oxford OX1 4EW. Books intended for review should be addressed to The Librarian, Hellenic Society, 31-34 Gordon Square, London, WG1H OPP 